\title{
A NEW SNAKE FROM THE EOCENE OF ALABAMA.
}

\author{
By F. A. LuCas, \\ Curator, Division of Comparatice Anatomy.
}

The name Pterosphenus schucherti is proposed for a large snake, indicated by about forty vertebræ from the anterior portion of the body, found associated with remains of Zeuglodon in the Eocene of Cocoa, Alabama.

\section{Type.-No. 4047, U.S.N.M.}

The most striking feature of the vertebræ, and the one on which the generic name is based, is the prolongation of the metapophysis upward and outward into a wing-like process. This character distinguishes the genus from all others. The species is named in honor of Mr. Charles Schuchert, by whom it was obtained.

The bodies of the vertebræ are slightly shorter than in Palcophis and the spinous processes, as shown by the only perfect example (Plate XLV, figs. 1-3), are very high and their bases coextensive with the neural arch.

The height of the spinous process, however, is but little more than in Boa or Ancistrodon, although it looks higher from the shortness of the centrum.

Hypapophyses are present or indicated on all the vertebræ. On the foremost, which from its size must be very close to the skull, the hypapophysis, arises as usual from the posterior portion of the vertebra and is directed as usual backward. The next complete hypapophysis, ten or fifteen vertebræ back of the foremost, extends directly downward. All succeeding hypapophyses are directed downward or incline slightly forward, a totally different arrangement from that found in other serpents.

About twenty or twenty-five vertebræ behind the foremost the hypapophyses are doubled in number-one, quite low and pointing forward, arising from the anterior part of the centrum, the second, or principal hypapophysis, being on the posterior part of the centrum. The two processes are connected by a low ridge. The facets for the ribs are pedunculate, as in Palceophis, and, as in that genus, a ridge extends from the anterior zygapophysis to the costal facet.

The sockets are as wide as or in some cases slightly wider than, high. The balls are slightly triangular in outline, although in most cases this is exaggerated by the abrasion of their edges. 
The articular faces look more directly backward and forward than they do in modern snakes with which this specimen has been compared, the difference between this species and Python being very marked. The zygapophyses agree with those of Palcophis in their slight lateral extent, a feature which gives the body of the vertebra a compact, compressed appearance, and contrasts with the wide-spread facets of Python. The facets of the zygosphene look more or less downward, contrasting very strongly with those facets in Python which lock obliquely outward, as they do in Palcophis. The facets of the anterior zygapophyses and zygosphene and those of the posterior zygapophyses and zygantrum lie nearly in parallel planes instead of converging, as in Python.

On each side of the zygantrum, just above the facet, is a foramen communicating with a cavity running well up toward the anterior zygapophysis, and this in turn communicates with a cavity at the base of the neural spine and one on each side of the body of the vertebra. (See Plates XLV and XLVI.) This feature exaggerates a character found in Python, and other snakes as well, but in Python the foramen is minute and the cavities smaller.

This species may be provisionally included in the Palcophida, although, as we know nothing of the structure of skull of either Palceo$p$ his or the present species, the exact relations of both are uncertain.

This species may not have been marine, although found with Zeuglodon, for a large Emyd was also found associated with it. It does, however, appear probable that it was aquatic.

The spinous processes are high, as in the semiaquatic Boa and Ancistrodon, but the force of this is weakened by the fact that in the strictly aquatic Pelamys the spinous processes are low. On the other hand, the low point of articulation of the ribs, as in Pelamys, and the comparatively high compressed character of the vertebræ generally. indicate a correspondingly compressed body, such as would be best adapted for swimming.

From the size of the vertebræ it is evident that the specimen was from 20 to 25 feet in length.

\section{EXPLANATION OF PLATES.}

Plate XLV.

Figs. 1-3. Anterior, left lateral, and posterior views of a dorsal vertebra, natural size.

4. Posterior view of a dorsal vertebra, showing the large foramina on either side of the zygantrum, natural size.

5. Left lateral view of a dorsal vertebra, showing the double hypapophysis, natural size.

Drawn by J. C. McConnell.

\section{Plate XLVI.}

Various views of vertebræ, showing range of size and details of structure, about three-fourths natural size. 


\section{$2 \mathrm{BHL}$ Biodiversity Heritage Library}

Lucas, Frederic A. 1898. "A new snake from the Eocene of Alabama." Proceedings of the United States National Museum 21(1164), 637-638. https://doi.org/10.5479/si.00963801.21-1164.637.

View This Item Online: https://www.biodiversitylibrary.org/item/53529

DOI: https://doi.org/10.5479/si.00963801.21-1164.637

Permalink: https://www.biodiversitylibrary.org/partpdf/52615

\section{Holding Institution}

Smithsonian Libraries

\section{Sponsored by}

Smithsonian

\section{Copyright \& Reuse}

Copyright Status: Public domain. The BHL considers that this work is no longer under copyright protection.

This document was created from content at the Biodiversity Heritage Library, the world's largest open access digital library for biodiversity literature and archives. Visit BHL at https://www.biodiversitylibrary.org. 